\title{
ВНЕУРОЧНАЯ ДЕЯТЕЛЬНОСТЬ
}

УДК 374 (091)

DOI 10.23951/2307-6127-2021-1-29-34

\section{К ВОПРОСУ О СТАНОВЛЕНИИ ПОНЯТИЯ «ВНЕУРОЧНАЯ ДЕЯТЕЛЬНОСТЬ» В РОсСИИ}

\section{О. В. Лингевич}

Томский государственный педагогический университет, Томск

На основе проведенного историко-педагогического анализа выявлено содержание понятий «внешкольная работа», «внеклассная работа», «внеучебная деятельность», «внеурочная работа». Предлагается периодизация этапов становления внеурочной деятельности школьников, описываются особенности организации внеурочной деятельности обучающихся на различных исторических этапах становления данного феномена в России: 1) возникновения феномена «внешкольной работы» в российском образовании, особенности которого связаны с созданием сети внешкольных учреждений «частной и общественной инициативы», направленностью их деятельности на общее развитие детей непривилегированных классов; 2) эволюции форм внешкольной, внеклассной, внеурочной деятельности обучающихся в образовательных организациях, чье своеобразие было обусловлено развитием массовой практики организации внешкольной (внеклассной, внеурочной) деятельности (включая создание «индустрии» досуговой деятельности детей и молодежи по месту жительства), интенсификацией научных исследований, в том числе содержанием данной работы, определением ее оптимальных задач, технологий, форм реализации; 3) становления современных моделей организации внеурочной деятельности, связанном с формированием в рамках системно-деятельностной образовательной парадигмы личностных и метапредметных образовательных результатов обучающихся.

Ключевые слова: внеурочная деятельность, внешкольная деятельность, внеклассная деятельность, внеучебная деятельность, этапы становления понятия «внеурочная деятельность».

Становление понятия «внеурочная деятельность» обусловлено логикой развития российского общества, процессами, происходящими в образовательной практике, следовательно, в разное время в зависимости от идеологических и культурных потребностей общества смысл и содержание этого термина изменялись. В настоящее время оно закреплено нормативно [1].

В теории и практике отечественного образования изначально доминировали термины «внешкольная», «внеклассная», «внеучебная», «внеурочная» работа. Выделяются следующие этапы развития данных видов деятельности: дореволюционный (до 1917 г.), советский (1917-2010 гг.) и современный (с 2010 г.).

Обратимся к характеристике отдельных этапов.

Возникновение феномена «внешкольной работы» в российском образовании (до 1917 г.). Анализ педагогической литературы позволил установить, что «внешкольное образование» как явление впервые появляется в педагогической литературе в конце XIX в. [2, 
3]. Можно констатировать, что данный феномен был описан и в научно-педагогической литературе [4-7]. Внешкольное образование было тогда представлено как система просветительских учреждений, организаций и мероприятий «просветительского характера для народных масс» $[6,7]$.

В этот период во многих губернских и даже уездных городах создавались первые внешкольные учреждения и организовывались досуговые мероприятия [2]. Так, в апреле 1898 г. в харьковском парке, по инициативе первого декана лесного отделения Петровской земледельческой и лесной академии В. Т. Собичевского, был реализован первый в России школьный праздник по посадке деревьев, участие в котором приняли 28 народных училищ города.

Приведем пример организации культурно-просветительской работы в г. Томске - одном из крупнейших центров Сибири начала XX в. Необходимость в таком виде деятельности с детьми и молодежью стала осознаваться на рубеже XIX-XX вв. и томской городской общественностью. Первого января 1863 г. по инициативе Д. Л. Кузнецова в Томске открывается публичная библиотека на базе Томской губернской мужской гимназии. Через год приехавшие из Петербурга Г. Потанин и Н. Ядринцев создали кружок, который посещали учащиеся женской и мужской гимназии при редакции «Томских губернских ведомостей». В 1865 г. были организованы первые публичные лекции с участием преподавателя истории из Красноярска С. С. Шашкова. Позднее П. И. Макушиным создается «Общество попечения о начальном образовании в Томске», на базе которого были открыты классы по техническому и ремесленному рисованию. Под эгидой общества с 1890 по 1891 г. действовали женские рисовальные классы, руководила которыми художница А. С. Капустина, также организовывались литературные вечера, на базе кожевенного завода Б. Л. Фуксмана был создан любительский театр [6].

В 1895 г. В. С. Пирусским было создано «Общество содействия физическому развитию». Целью данного общества было укрепление детского физического здоровья и отвлечение взрослых от алкоголизма [6]. Также под руководством В. С. Пирусского в 1913 г. было достроено первое в России внешкольное учреждение. Школа-манеж включала: большой зал для подвижных игр, бега, гимнастики; комнаты для занятия ручным трудом; библиотеку; врачебный кабинет и т. д. [6]

В Москве первые клубы, детские сады, имеющие название «Дневной приют для приходящих детей», были созданы усилиями С. Т. Шацкого [8] и А. У. Зеленко [2]. На базе данных заведений насчитывалось три мастерских и культурно-просветительское общество «Сетлемент», цель которого заключалась в удовлетворении культурных и социальных потребностей детей и молодежи, лишенной возможности в получении школьного образования.

Таким образом, это этап создания сети внешкольных учреждений «частной и общественной инициативы», т. е. множества взаимосвязанных самостоятельных учреждений внешкольного образования, деятельность которых была направлена на общее развитие детей непривилегированных классов.

Второй этап - этап эволюции форм внешкольной, внеклассной, внеурочной деятельности обучающихся в образовательных организациях (1917 г. - конец XX в.). На основании анализа историко-педагогических трудов и монографий по исследуемому периоду можно предположить, что в начале 20 -х гг. XX в. широко распространились идеи С. Т. Шацкого [8] о технологиях развития социальной активности детей. Велись серьезные научные исследования и наблюдения за развитием творческих способностей личности, ее интересов и потребностей, изучались коллективные и групповые формы работы [3]. 
В годы Великой Отечественной войны развитие сети внешкольных учреждений замедлилось. Часть из них, попавшая в зону боевых действий, была разрушена, а в уцелевших помещениях домов пионеров размещались штабы и госпитали. В этот период усиливалось патриотическое направление во внешкольной работе с детьми. Развивались такие формы работы, как политинформации, агитбригады, встречи с фронтовиками и т. д. [9].

Период с 1961 по 1986 г. - это этап наивысшего развития внеклассной деятельности в $\mathrm{CCCP,} \mathrm{особенности} \mathrm{которой} \mathrm{были} \mathrm{связаны} \mathrm{с} \mathrm{организацией} \mathrm{досуговой} \mathrm{деятельности} \mathrm{детей,}$ развития их творческих способностей в учреждениях дополнительного образования, предметной внеклассной деятельности школьников.

Так, в Томской области в 70-е гг. XX в. массово организовывались школьные археологические экспедиции, краеведческие экспедиции, экспедиции «красных следопытов» и т. д. Так, ученикам с. Саровки при участии Колпашевского краеведческого музея удалось организовать археологическую экспедицию, результатом которой стали археологические находки. «Красные следопыты» школы № 4 совершили поход по местам боевой славы с целью собрания материала о герое Советского Союза Иване Черных. Школьники г. Томска и г. Асино приняли участие в экспедиции «Летопись Великой Отечественной», организованной на базе образовательных организаций, с целью дополнения новыми документами музеев боевой славы. Отряд «Искатель» под руководством О. М. Утьева совершил поход на байдарках по реке Бия.

В 1985 г. правительство начинает курс на перестройку всей общественной жизни. Происходит распад однопартийной системы и, как следствие, постепенное разрушение советской системы внеурочной деятельности. Сокращается сеть турбаз, кружков, клубов, возрастает криминализация, происходит рост безработицы, снижение уровня физического и психического здоровья молодежи.

Таким образом, это этап формирования государственной модели внешкольной, внеклассной работы, особенности которого обусловлены развитием массовой практики организации внешкольной (внеклассной, внеурочной) деятельности (включая создание «индустрии» досуговой деятельности детей и молодежи по месту жительства), интенсификацией научных исследований, в том числе содержанием данной работы, определением ее оптимальных задач, технологий, форм реализации.

Третий этап - этап становления современных моделей организации внеурочной деятельности (с 2011 г. по настоящее время). Поэтапное введение ФГОС общего образования, направленных на формирование нового содержания образования, предопределило начало современного этапа становления понятия «внеурочная деятельность» как обязательной части образовательного процесса, реализующейся образовательными организациями в сотрудничестве с учреждениями дополнительного образования в рамках конкретных направлений $[10,11]$.

Анализ изменений, происходящих на современном этапе становления понятия «внеурочная деятельность», позволяет сделать вывод, что это целенаправленная, образовательно-воспитательная деятельность [12], которая осуществляется в формах, отличных от классно-урочных, и направлена на разностороннее раскрытие индивидуальных способностей обучающихся, развитие интереса к различным видам деятельности, умения самостоятельно организовывать свое свободное от занятий время. Каждый из видов внеурочной деятельности способствует формированию коллективного взаимодействия.

Таким образом, анализ процесса становления современных представлений о феномене внеурочной деятельности осуществлялся в рамках следующих историко-педагогических этапов: 
Этап возникновения феномена «внешкольной работы» в российском образовании (до 1917 г.) - это этап создания самостоятельных учреждений внешкольного образования, особенности которого связаны с направленностью на создание сети внешкольных учреждений «частной и общественной инициативы», общее развитие детей непривилегированных классов.

Этап эволюции форм внешкольной, внеклассной, внеурочной деятельности обучающихся в образовательных организациях (1917-2010 гг.) - это этап формирования государственной модели внешкольной, внеклассной работы, особенности которого обусловлены развитием массовой практики организации внешкольной (внеклассной, внеурочной) деятельности (включая создание «индустрии» досуговой деятельности детей и молодежи по месту жительства, обязательность внеурочной работы для субъектов образовательного процесса), интенсификацией научных исследований, в том числе содержанием данной работы, определением ее оптимальных задач, технологий, форм реализации.

Этап становления современных моделей организации внеурочной деятельности (с 2011 г. и по настоящее время) - это этап становления современных моделей организации внеурочной деятельности, специфика которого связана с формированием в рамках системно-деятельностной образовательной парадигмы современного целеполагания, деятельностных подходов к организации урочной и внеурочной деятельности обучающихся.

\section{Список литературы}

1. Тестова Я. А. Модель организации внеурочной деятельности в условиях опережающего введения ФГОС OОО // Официальный сайт учителя биологии Я. И. Тестовой. URL: https://www.sites.google.com/a/sch87.ru/ testova/home (дата обращения: 14.10.2020).

2. Дополнительное образование детей: учебное пособие для студентов высших учебных заведений / под ред. О. Е. Лебедевой. М.: Владос, 2003. 256 с.

3. Абрамов Я. В. Хроника народного образования // Русская школа. 1903. № 2. С. 15-16.

4. Дейч Б. А. Проблемы внешкольного образования в российской научно-педагогической литературе конца ХІХ - начала XX в. // Народный учитель. 1907. № 10. С. 4.

5. Евладова Е. Б., Логинова Л. Г., Михайлова Н. Н. Дополнительное образование детей: учебное пособие для студентов учреждений сред. проф. образования. М.: ВЛАДОС,2002. 352 с

6. Лобанов В. В., Ревякина В. И. Педагогика доктора Пирусского: новаторские опыты оздоровительно-образовательной работы в Сибири конца XIX - начала XX в. / Томский гос. пед. ун-т. Томск: Изд-во ТГПУ, 2013. 202 c.

7. Методика обучения иностранным языкам в средней школе: учеб. / Н. И. Гез и др. М.: Высшая школа, 1982. $373 \mathrm{c}$.

8. Шацкий С. Т. Что такое клуб? // Собр. соч.: в 2 т. М.: Академия пед. наук РСФСР, 1980. Т. 1. С. 259.

9. Ромм Т. А. Становление и развитие социальной педагогики в России в конце XIX - начале XX века: дис. ... канд. пед. наук. М., 1995. 165 с.

10. Педагогическая энциклопедия: в 4 т. Т. I / под ред. И. А. Каирова. Советская энциклопедия. М.: Академия пед. наук РСФСР, 1964. 831 с.

11. Педагогический словарь / под ред. И. А. Каирова. М.: Академия пед. наук РСФСР, 1960. 1544 с.

12. Сластёнин В. А., Исаев И. Ф., Мищенко А. И., Шиянов Е. Н. Педагогика: учеб. пособие. М.: Школа-Пресс, 1997. $512 \mathrm{c}$.

Лингевич Ольга Владимировна, старший преподаватель, Томский государственный педагогический университет (ул. Киевская, 60, Томск, Россия, 672241).

E-mail: @sibmail.com

Материал поступил в редакцию 08.12.2020 
DOI 10.23951/2307-6127-2021-1-29-34

\section{TO THE QUESTION ABOUT THE FORMATION OF THE CONCEPT "EXTRACURRICULAR ACTIVITIES" IN RUSSIA}

\section{O. V. Lingevich}

\section{Tomsk State Pedagogical University, Tomsk, Russian Federation}

On the basis of the conducted historical and pedagogical analysis, the content of the concepts "afterschool work", "out-of-class work", "nonlearning work", "extracurricular work" was revealed. The periodization of the stages of the formation of extracurricular activities of schoolchildren is proposed; describes the features of the organization of extracurricular activities of students at various historical stages of the formation of this phenomenon in Russia: 1) at the stage of the emergence of the phenomenon of "extracurricular work" in Russian education, the features of which are associated with the creation of a network of extracurricular institutions of "private and public initiative", the focus of their activities on the general development of children of unprivileged classes; 2) at the stage of evolution of forms of extracurricular, extracurricular, extracurricular activities of students in educational organizations, whose originality was due to the development of mass practice of organizing extracurricular (extracurricular) activities (including the creation of an "industry" of leisure activities for children and youth at the place of residence), intensification of scientific research, including the content of this work, determining its optimal tasks, technologies, forms of implementation; 3) at the stage of formation of modern models of organization of extracurricular activities associated with the formation of personal and metasubject educational results of students within the framework of the system-activity educational paradigm.

Keywords: extracurricular activities, afterschool activities, out-of-class activities, nonlearning activities, stages of formation of the concept of "extracurricular activities".

\section{References}

1. Testova Ya. A. Model' organizatsii vneurochnoy deyatel'nosti v usloviyakh operezhayushchego vvedeniya FGOS OOO [The model of organizing extracurricular activities in the context of the advanced introduction of the Federal State Educational Standard]. Offitsial'nyy sayt uchitelya biologii Ya. I. Testovoy [Official site of the teacher of biology Ya. I. Testova] (in Russian). URL: https://www.sites.google.com/a/sch87.ru/testova/home (accessed 14 October 2020).

2. Lebedeva O. E. (ed.) Dopolnitel'noye obrazovaniye detey: uchebnoye posobiye dlya studentov vysshikh uchebnykh zavedeniy [Additional education for children: study guide for university students.]. Moscow, VLADOS Publ., 2003. 256 p. (in Russian).

3. Abramov Ya. A. Khronika narodnogo obrazovaniya [Chronicle of public education]. Russkaya shkola, 1903, no. 2, pp. 15-16 (in Russian).

4. Deych B. A. Problemy vneshkol'nogo obrazovaniya v rossiyskoy nauchno-pedagogicheskoy literature kontsa XIX - nachala XX v. [The problems of out-of-school education in the Russian scientific and pedagogical literature of the late 19th - early 20th centuries]. Narodnyy uchitel', 1907, no. 10, p. 4 (in Russian).

5. Evladova E. B., Loginova L. G., Mikhaylova N. N. Dopolnitel'noye obrazovaniye detey: uchebnoye posobiye dlya studentov uchrezhdeniy srednego professional'nogo obrazovaniya [Additional education for children: textbook for students of institutions of secondary vocational education]. Moscow, VLADOS Publ., 2002. 352 p. (in Russian).

6. Lobanov V. V., Revyakina V. I. Pedagogika doktora Pirusskogo: novatorskiye opyty ozdorovitel'no-obrazovatel'noy raboty v Sibiri kontsa XIX - nachala XX vv. [Pedagogy of Doctor Pirusky: Innovative Experiences in HealthImproving and Educational Work in Siberia in the Late 20th - Early 20th Centuries]. Tomsk, TSPU Publ., 2013. 202 p. (in Russian). 
7. Metodika obucheniya inostrannym yazykam v sredney shkole: uchebnik [Methodology for teaching foreign languages in secondary school: tutorial]. Moscow, Vysshaya shkola Publ., 1982. 373 p. (in Russian).

8. Shatskiy S. T. Chto takoye klub? [What is a club?]. Sobraniye sochineniy v 2 tomakh [Collection of works. 2 volumes]. Moscow, Academy of Pedagogical Sciences of the RSFSR Publ., 1980. Vol. 1, p. 259 (in Russian).

9. Romm T. A. Stanovleniye i razvitiye sotsial'noy pedagogiki v Rossii v kontse XIX-nachale XX veka. Dis. kand. ped. nauk [Formation and development of social pedagogy in Russia in the late 19th - early 20th centuries. Dis. cand. ped. sci.]. Moscow, 1995. 165 p. (in Russian).

10. Kairov I. A. (ed.) Pedagogicheskaya entsiklopediya: v 4 t. T. I. Sovetskaya entsiklopediya [Pedagogical encyclopedia. 4 volumes. Vol. I. Soviet encyclopedia]. Moscow, Academy of Pedagogical Sciences of the RSFSR Publ., 1964. 831 p. (in Russian).

11. Kairov I. A. (ed.) Pedagogicheskiy slovar' [Pedagogical Dictionary]. Moscow, Academy of Pedagogical Sciences of the RSFSR Publ., 1960. 1544 p. (in Russian).

12. Slastenin V. A., Isayev I. F., Mishchenko A. I., Shiyanov Ye. N. Pedagogika: uchebnoye posobiye [Pedagogy. Tutorial]. Moscow, Shkola-Press Publ., 1997. 512 p. (in Russian).

Lingevich O. V., Senior Lecturer, Tomsk State Pedagogical University (ul. Kiyevskaya 60, Tomsk, Russian Federation, 634041).

E-mail:@sibmail.com 